the same saddened, anxious faces and malnutrition of the body that are present in the other sex. In them also clearing away a couple of pounds of cæcal concretions changes the men in spirits and health permanently. I refer to police officers whose tours of duty are one month day work and next month night work.

In one case in point the following record was given. On July 10th, 1897, he was attacked with "appendicitis" which lasted for 26 days. On Dec. 22nd of the same year be was seized with "abdominal pains," being ill for 20 days. On Nov. 2nd, 1898, "dyspepsia" came on and lasted for 18 days. In 1899 he suffered from "constipation" for 19 days. On July 11th, 1899, he was again attacked with "appendicitis" which lasted for 91 days. This long list means that the man was not cured till the last occasion. The shorter treatment permits only of clearing out the colon and removes one of the two conditions necessary to so-called appendicitis. The patient is therefore safe for the present. But the cæcal concretions remain, the colon gets blocked again, with a return to the sick list. He called on me in February, 1903, and his account of himself is worth recording.

On the first occasion (July, 1897) he went to St. Thomas's Hospital, where he "lay in bed for a week and had milk and castor-oil only." The last time (July, 1899) he was under my care as his divisional surgeon. "I was in a terribly weak state and walked about in misery always. I was always tired and wanted to lie down; always in very low spirits. I felt regularly weak; knocked up. I could not eat or drink anything; if I did I brought it up. I don't want to have a bout like that again." Persistent enemata with large doses of olive oil taken internally two or three times daily constituted the treatment. The concretions began to come away in about six weeks. I continue his narrative. "The stones came away nearly white, about the size of a pea, and a lot of phlegm-stuff with them; a good many of them at different times, loose in the injections, always floated, soft looking" (the effect of the oil); "I never touched any food till they came away. They were coming away for a week or a fortnight. I should think quite a couple of pounds. I never felt ill since and had no return of the stones (i.e., over three years). I am quite different. I can eat and drink anything and enjoy a good dinner and do a bit of gardening." He looks plump and cheerful and he still retains his vermiform appendix.

A third type is constantly obtruding itself on the general practitioner and calling for his help. It includes the large class suffering from "windy spasms." It might be called the " borborygmous type." The following is a case in point.

The patient, a married woman, aged 38 years, was a strong active, well-nourished person engaged in a very trying business. Her abdominal girth was so great that she had not been able to stoop. It was so obtrusive and obstructive that conversation with her could only be carried on at a considerable distance. Her facial lines also were coarse and bloated. For years she had suffered from wind, pain in the descending colon and above it, constipation, frequent faintness, palpitation, breathlessness (terrifying her with a fear of impending death), loss of appetite, and discomfort so great as to drive her frequently for relief to alcoholic stimulants. Two years ago I told her that she could be cured only by submitting to a six weeks' course of treatment to empty her cæcum. But this did not commend itself to her. She had only palliatives and temporary relief from aperients from many sources. At last, on March 21st, 1903, she was so very unwell and low-spirited from her continual ill-health that she asked me to undertake what $I$ had so often recommended, hoping that I might not require six weeks. I told her the probability now was that a longer time would be required to finish the work, more likely three months, but in any event she was to permit me to finish it and then promised she would be free from her constant illness.

The case is of great interest in many ways and I kept an account of my daily work but will here give only a few extracts. The colon was choked from beginning to end with a large cushion of sulphuretted hydrogen saturated, hard, fusiform fæces. On April 22nd, after a month, she could feel the warm enema trickling up and across and, when she turned on her right side, down the colon to the cxcum. A few whitish specks like " curdled milk" (mucin) appeared floating on the surface of the returned enema. She had observed it two or three times already. I promised her a closer and larger knowledge of them before lrng. On the 25th she had a clear, free drain-pipe (the colon) that would carry off any amount of gas (34 days). On the 27th I was greeted with the following: "I had such a lot of very funny stuff come away after you left on Saturday (25th), a lot of white jelly stuff, clear, and the pieces as big as the top of that bottle (two inches in diameter). I never had such stuff come from me and such a lot of it." I reminded ber of my promise of the 22nd that she would see much more of the jelly. My previous case had drawn my attention to this jelly where the surface of the water had been covered with a layer of pieces like "curdled milk," which pieces the microscope showed to be mucin with its numerous variously shaped "goblet cells." Occurring again here and seeking for its meaning I could only think that the jelly had stood between me and the concretions, forming a pellicle over them which the stream of water had broken up and washed away, then only allow. ing me to act on the old, hard, dry concretions. When I had entirely got rid of these (in 37 days) on May 26th my opinion was strengthened by a similar pellicle coming away whole and with a tail hanging from it in the shape and position of an appendix. On the 26th the following note was made : "Fnema brings away an empty bag in the siape of the end of the cæcum with a prolongation like an appendix but much larger." There was no sign of abscess or inflammation in all this and the pyogenic-looking membrane was a tough protecting layer with probably a physiological function rendering these old concretions harmless. The membrane was accompanied by some dozen or less small typical concretions, fresh for the first time. (65 days passed before the appearance of fresh concretions.) The cæcal contents had been open to attack from the time the large jelly stool appeared on April 19th, 27 days after commencement of treatment. Therefore the actual washing away of the cæcal contents required 37 days.

As the case progressed the patient's facial lines became finer, her protuberant abdomen receded, and she could stoop when she was reduced to 52 inches, about half way through the treatment. On May 27th the following note was recorded : "A special interest in this case was the persistent hardness and dryness of the creal concretions, never to the end coming away in masses like most others." On June 20th the bowels had acted two or three times every day without aperient-"a baby's really." The patient felt better, could talk better, think better, and for the first time acknowledged the complete benefit which she had derived from this long anxious work. She said that her husband also saw it as did all her friends.

There is a class of cases, the largest of all, from which I expect the most striking evidence of benefit from this treatment. I have not had the opportunity of putting my practice to the test in this field, but as a district medical officer since 1868 I have had only too ample means of forming an opinion and that is one of dissatisfaction with the constant march of so many, young and old, to lunatic asylums. I know the profound effect on the mind produced by a loaded cæcum and the return to mental health when it is emptied. I have seen epileptic fits caused apparently by it only and stopped by the treatment. Peripheral irritation also seems to be the only explanation of the terrible fits in puerperal eclampsia and $I$ recall cases of lunacy where now I would adopt this treat. ment before filling up the certificate. May not some, many of the thousands of patients in these asylums, be benefited by this treatment? The delusions in the first case would have warranted a certificate : emptyirg the cæcum dissipated them. The medical officers of asylums have an ample choice before them ; I ask them to help on the inquiry. It is worth while emptying the cæcum.

\section{NOTES ON THE ETIOLOGY OF LUPUS AND ON CASES TREATED BY THE} $X$ RAYS AND FINSEN LIGHT.

BY FRANK H. JACOB, M.D., M.R.C.P. LOND,

PHYSICLAN TO OUT-PATIENTS AND TO THE ELECTRICAL TREATMEAT DEPARTMENT, NOTTLNGHAM GENERAL HOSPITAL.

I HAVE attempted to work out the personal susceptibility and also the actual source of infection in 30 cases of lupus under my care with the following results. In 22 of the cases there was a history of phthisis in near relatives, while in eight no such history could be obtained. In three cases the lupus appeared while the patient was actually nursing a case of phthisis and in one while nursing a case of hip disease 
with a discharging sinus. In three cases lupus appeared in an infant whose parent was suffering from phthisis and in one case the father had died a year previously from phthisis. One patient habitually used the same towel as her sister who was suffering from lupus. In two cases the disease arose on the wrist of a patient suffering from phthisis. In one case it arose from the margin of a wound left after excision of glands in the neck and in two cases it arose from the margin of a chronic abscess in the neck. In one case it occurred in the wound caused by a blow over the tibia. Thus in 15 cases the origin could be traced with tolerable certainty. In addition I may mention that six cases presented blocking of a nasal duct previously to the appearance of lupus of which cases four were probed prior to the onset of this disease.

Treatment of the cases of lupus. - The treatment which $\mathrm{I}$ now believe to be the most efficacious is as follows. For extensive cases the $x$ rays should be applied as a routine treatment for ten minutes three times a week. I aim always at producing a mild reaction, as in my experience a reaction leads to a more rapid result. For special cases modifications are necessary. For example, I have one patient the whola of whose face (except the forehead), left arm, left foot (except the sole) and leg up to the knee were affected with rapidly spreading active lupus; that on the face was of the superficial plaque variety; on the arm and leg it was likewise of the plaque variety but deeper, the dorsum of the fingers showed a markedly verrucose condition, the ley was very much thickened, and the dorsum of the foot was ulcerated. The face, arm, and leg were each treated twice a week with 20 minutes' exposure on each occasion. Now, after two years' treatment I can only find on the face two small areas close to the ear of about the size of a threepennypiece, on the arm no lupus at all, on the leg a few small areas close to the knee, the thickening is markedly less, and the ulcer has long ago healed. These few peripheral portions are now receiving special attention and will soon be cured. Another patient lives a long distance away and is moreover very poor, consequently she is only able to attend at intervals varying from four to eight weeks; she then stops a week-end with relatives in the town and has 20 minutes exposure on Saturday, Monday, and Tuesday. This causes a distinct reaction. She had originally a very thick patch on the left cheek of ten years' duration, about two by one and a half inches in diameter. After 18 months' treatment she is now almost cured, there being just a little very thin lupus at the upper margin.

For ulcerated septic cases the $\mathrm{x}$ rays have proved most admirable, cleaning and healing being completely established in from four to eight weeks; the subsequent curing of the lupus of course takes very much longer.

Deep nodules formerly gave me considerable trouble as they were apt to persist when the more superficial portions had entirely disappeared. In my cases the deepest nodules have been situated in the centre of the cheek and in the cartilaginous portion of the nose. I now treat them as follows. With a wooden match I place a small drop of pure phenol on the top of the nodule; when the surface is thoroughly anæsthetic I penetrate the nodule with a pointed match dipped in pure carbolic acid and when the deeper portion is also anæst betic I thoroughly rub the carbolic acid into the nodule, then while the part is still white from the carbolic acid I apply the Finsen lamp (London model), limiting its action to the area required in order that I may induce a somewhat severe reaction without unduly punishing the patient. This repeated some three or four times is usually sufficient to establish a cure. The disadvantage of this treatment is that it is liable to leave small pits.

I reat small limited arfas in the same manner as the deep nodules, in some cases producing a reaction with the $x$ rays instead of the Finsen lamp. The result is very satisfactory and the most, rapid with which I am acquainted.

Rodent ulser - It is an advantage of life in a small town that one is able to trace the after-bintory of cases with more readiness than is posuible in London. This after-history shows recurrence to be extremely frequent; this is, I believe, due in a great majority of the cases to in $-\mathrm{uffi}$ :ient treatment. Inasmach as the disease is not the ulcer but the new growth it is obviously necessary to continue treatment until every suspicion of new growth has disappeared and if this be rignrously carried ont I believe that recurrence will hecome as rare as it is now common. There is, however, another cau-e of recurrence - viz., that the ulcer is due to a true carcin $\mathrm{m}$ of the skin and is not a rodent ulcer. I have one such case with deep excavation and very thick hard margins, which though once healed by the $x$ rays recurred and has progressed rapidly in spite of treatment.

H czema.-Two cases of eczema of the palm have been treated by the $x$ rays; they both presented great thickening of the horny layer of the epidermis, which was traversed by deep bleeding cracks; for eight years one, and for seven years the other, had been unable to perform even light household duties such as dusting. The first case after six months' treatment was completely cured and now remains after three months without a relapse, though she does ber own scrubbing. The second case was cured by one month's treatment, the diminished length of treatment being due to my experience of the first case having taught me that the necessary factor in the treatment was to produce sufficient dermatitis to cause active desquamation.

Ringworm.- - It was in July I first treated ringworm by depilation by means of the rays; since then my aim has been to reduce the number of exposures necessary to obtain depilation to the minimum and to produce it without any reaction, for my experience with lupus in hairy parts taught me that no trace of reaction is necessary for this purpose. With my apparatus I can accomplish this by two applications of half an hour each at intervals of a fortnight. I am now aiming at depilating only the affected hairs and in one case I have, I believe, effected this.

Lupus erythematosus. - I have only completed treatment in one case and that a chronic patch of the sebaceous type of e'ght years' duration occurring on the nose. This has now been completely cured for four months and shows no indication of relapsing.

With respect to apparatus, the essential point is to know your own plant, more especially your tubes, and when in doubt to try them on yourself, so that you may be certain of either not producing a reaction or inducing that degree of dermatitis which you may desire without risk of producing a seriou: burn.

Nottingham.

\section{d a thrtor}

\section{HOSPITAL PRACTICE, BRITISH AND FOREIGN.}

Iulla sutem est alia pro certo noscendi via, nisi quamplurimas et morborum et dissectionum historias, tum aliorum tum propras sollectas habere, et inter se comparare.-Morgagni De Sed. et Caus. Morb., lib. iv., Procemium.

\section{UNIVERSTTY COLLEGE HOSPITAL.}

\section{A CASE OF LONGITUDINAL FRACTURE OF THE TIBIA.}

(Under the care of Mr. RICKMAN J. GODLEE.)

Fon the notes of the case we are indebted to Mr. J. B. Burt, late house surgeon.

A man, aged 46 years, was admitted into University College Hospital on Nov 21st, 1903. Whilst getting off an omnibus he struck his left knee forcibly against the mudguard behind the wheel. He was able to stand after the accident but on attempting to walk fell down. On admission to the hospital the injured leg was so painful that any accurate examination was impossible. The leg was swollen and the knee joint was distended; it was evident that there was some severe injury about the joint but its exant nature conld not be made out without an anæ,thetic.

Under chloroform the physical signs were as follows: 1. Genu valgum-this deformity could be reduced by extension applied to the foot. 2. Undue lateral mobility of the tibia on the femur but no increased antero posterior mobility. 3 An increase of the width of the upper end of the tibia; measured with callipers the greatest width of the npper end of the right tibia equalled three and a balf inches and the greatest width on the left side was four inches. Perhaps some slight allowance should be made for the cdema in the latter case. 4 An undue projection outwards of the external tuberosity of the tibia without an equal dis placement of the internal tuberosity. 5 No evidence of a transverse solation of continuity of the $f \in m u r$ or the tibis. 6. When the upper end of the tibia wus compressed laterally a clicking sensation was felt. There was also 